\title{
IAMJ
}

INTERNATIONAL

AYURVEDIC

MEDICAL JOURNAL

ISSN: 2320-5091

Impact Factor: 6.719

\section{MANAGEMENT OF TUBAL BLOCKAGE BY UTTARA BASTI - A CASE REPORT}

\section{Chauhan Monika}

Associate Professor, PTSR Dept., Patanjali Ayurveda College, Haridwar and PhD Scholar in Parul Ayurveda College, Vadodara, Gujarat, India

Corresponding Author: Chauhandrmonika1@gmail.com

https://doi.org/10.46607/iamj17p5032021

(Published online: March 2021)

Open Access

(C) International Ayurvedic Medical Journal, India 2021

Article Received: 18/03/2021 - Peer Reviewed: 25/03/2021 - Accepted for Publication: 27/03/2021

Check for updates

\begin{abstract}
A clinical study was carried out with the aim of clinical evaluation of effect of Uttara basti with Apamarga Kshara Taila in bilateral tubal block. Achievement of conception depends on the fertility capacity of both the male and female partner; male is directly responsible in around $30 \%$ of cases, female in $30 \%$ and both are responsible for $30 \%$ of cases, and in the remaining $10 \%$ of cases cause remains unexplained As per the FIGO manual, Tubal factors are causing infertility in around 30 to $40 \%$ cases. Tubal factors include tubal injury, blockage, or paratubal adhesions. In the existing modern system of medicine, there is no proper intervention available to clear the tubal block. This condition is dealt with ART or invasive procedures like tubal reconstructive surgery which are not accessible to majority of population. This article presents a successfully managed case of Bilateral Tubal Blockage by Uttara Basti in the form of a case study. Uttara Basti was planned for duration of 3 months. Post treatment HSG revealed patent bilateral tubes and after 4 months she got conceived.
\end{abstract}

Keywords: Uttara Basti, Apamarga kshara taila, HSG, ART, Tubal block 


\section{INTRODUCTION}

Infertility is a disease of the reproductive system defined by the failure to achieve a clinical pregnancy after 12 months or more of regular unprotected sexual intercourse. ${ }^{1}$ Primary infertility is if the couple had never conceived despite cohabitation and exposure to the risk of pregnancy (absence of contraception). Secondary infertility is the infertility was labelled as secondary if the couple had failed to conceive following a previous pregnancy, despite cohabitation and exposure to the risk of pregnancy (in the absence of contraception, breastfeeding or postpartum amenorrhoea) for a period of 2 years. Among both the types of infertility tubal factor is reported to account for $25-35 \%$ of subfertility in the western medical literature, but the prevalence appears to be higher in India due to the higher rates of unrecognized pelvic inflammatory disease (PID) and tuberculosis. The fallopian tubes are two thin tubes, one on each side of the uterus, which help lead the mature egg from the ovaries to the uterus. When an obstruction prevents the egg from traveling down the tube, the woman has a blocked fallopian tube. It can occur on one or both sides. This is also known as tubal factor infertility and is the cause of infertility in $40 \%$ of infertile women. Each month, when ovulation occurs, an egg is released from one of the ovaries. The egg travels from the ovary, through the tubes, and into the uterus. The sperm also need to swim their way from the cervix, through the uterus, and through the fallopian tubes to get the egg. Fertilization usually takes place while the egg is traveling through the tube. If one or both fallopian tubes are blocked, the egg cannot reach the uterus, and the sperm cannot reach the egg, preventing fertilization and pregnancy. It's also possible for the tube not to be blocked totally, but only partially. This can increase the risk of a tubal pregnancy or ectopic pregnancy. If only one fallopian tube is blocked, but the other is clear, it may still be possible to achieve pregnancy. It depends on how well the ovaries are functioning, and also what caused the blocked tube in the first place ${ }^{2-5}$. In Ayurveda the clinical condition of female infertility is known as Stri vandhyatva. Harita has mentioned Vandhyatva as failure to achieve a child rather than pregnancy and included Garbhasrava (abortion) as well as Mritavatsa (stillbirth) conditions. Essential factors described for Garbhadharana (achievement of conception) are healthy Garbhasaya (Kshetra reproductive system), Ritu (season), Ambu (nourishing substances), Bija (ovum and sperm) and normalcy of Hridaya (psyche) along with normal function of Vayu (governing nervous system).

Any abnormality in these factors is lead to cause infertility. The word yoni refers to entire reproductive tract which includes uterus and adnexae. Tubal block can be considered under the Kshetravikriti. As per sage Harita infertility caused by tubal block can be considered under sixth type of female infertility i.e. Garbhakoshabhanga (abnormality in the uterus and adnexae) ${ }^{6}$ If both tubes are blocked it may be impossible to get pregnant naturally. This paper presents a case of primary infertility with bilateral tubal blockage.

\section{CASE REPORT}

A 34-year-old Indian, non-smoker, non-alcoholic married woman consulted in Out-Patient Department (OPD) of Patanjali Ayurveda Hospital on 23.10.2017 with complaint of inability to conceive since 3 years with latest hysterosalpingogram report dated 22.05.2017 suggestive of filing defects in uterine cavity with no free intraperitoneal spill on the right fallopian tube and restricted intraperitoneal spill on the left fallopian tube. On detailed history Husband's sperm count was normal. Couple was advised to undergo IVF (In Vitro Fertilization) treatment since her fallopian tubes were blocked.

\section{Procedure Done}

Patient was admitted for Uttar Basti as menses ceased on 6th day of cycle and advised to have a light meal in morning on the day of treatment. Abhyanga (massage) with Rasanadi Dashmool Taila and then Nadi Sweda (fomentation) of lower abdomen and back was done. After this Purvakarma, the patient was asked to lie down in dorsal lithotomy position, on the operation table. Thereafter, Yoni Prakshalana (Douching) by Panchvalkala Kwatha was performed to sterile the peri-vaginal part. The vaginal canal was cleaned with 
antiseptic solution. The vagina and cervix were visualized with the help of Sim's speculum and an anterior vaginal wall retractor. The anterior lip of the cervix was held with the help of Allis' forceps and uterine sound was inserted to ascertain size and position of uterus. Then $5 \mathrm{ml}$ medicated oil was pushed with the help of Intrauterine insemination (IUI) cannula, already attached with $5 \mathrm{ml}$ syringe filled with $\mathrm{Apa}$ marga Kshara Taila and the patient was kept in head low position. The drug slowly injected above the level of the internal OS. Instruments were removed and the patient was shifted to IPD ward. She was kept in head low position for at least 45 minutes for better absorption of drug. Uttar Basti was done for three times in one cycle on alternate days i.e. on 6th, 8th and 10 thday of menstrual cycle. The same procedure of Uttar Basti was repeated for next two consecutive menstrual cycles.

\section{Follow-Up and outcome}

HSG was done after completion of this treatment. Findings showed normal spill from both fallopian tube, there was no adverse or unanticipated event seen during whole regime. During follow up she got conceived after 4 months.

\section{DISCUSSION}

Term Artavavaha Srotasa covers the entire female reproductive tract and encompasses it as a structural \& functional unit. Word Artava is used for Raja, Beeja both in various places in classics. Thus, fallopian tubes can be termed as Artava Bija Vaha Srotasaas they carry Bija Rupi Artava (Ovum). Mainly Vata and Kapha are responsible for tubal blockage. Acharya Kashyapa has mentioned Vandhyatva as Nanatmaja Vikara of Vata. Narrowing (Samkocha) of tubal lumen is one of the main factors of tubal blockage and it is because of $\mathrm{Vata}^{7}$. Kapha has Avarodhaka property which leads to occlusion of tubal lumen. The drug considered effective to open the fallopian tube should have Vata Kapha Shamaka properties so Apamarga Kshara Taila is selected. Local administration of any drug containing Sukshma, Laghu, Sara, Vyavayi, Vikasi Guna, Katu Vipaka \& Ushna Virya has effective role in removing tubal blockage. Uttar Basti removes the blockage of tubal lumen by directly acting on obstruction and restores the normal endometrium. It restores the normal functions of cilia by stimulating it. It breaks the tubo-peritoneal adhesions, as it is observed with several studies that hystero-salpingography with oil-based dye helps to break the adhesions. It normalizes the tonic phasic contraction of muscles by pacification of Vata. It helps in scraping of obstructing substance and removes the fibrosed and damaged tubal lining and promotes its rejuvenation.

\section{CONCLUSION}

Infertile couples are forced to dwell upon assisted reproductive techniques (ART) or Reconstructive tubal surgery after diagnosis of tubal blockage as cause of infertility. But these techniques remain inaccessible to a significant proportion of infertile couples around the world. This can be explained by either the lack of specialized clinics in some countries or by the high cost of the procedures. So, this multi-modality Ayurveda treatment regime which includes Virechana, Aasthapan Basti, Anuvasana Basti, Uttar Basti may prove to be blessing to the sufferers and standard treatment for tubal blockage.

\section{REFERENCES}

1. WHO, multiple definitions of infertility cited on $4 / 4 / 17$ at 5:00 pm available from http://www. who. int/reproductivehealth/topics/infertility/multiple definitions/en/.

2. Conceiving After Tubal Surgery: Fact Sheet. American Association of Reproductive Medicine. Accessed November62008 ent Resources/Fact_Sheet_and_Info_Booklets/Concei vingAfterTub alSurger. pdf (8th Jan 2012)

3. Hydrosalpinx: Fact Sheet. American Association of Reproductive Medicine Acessed November 6,2008.http://asrm.org/uploadedFiles/ASRM_Content/ Resources/Pati ent_Resources/Fact_Sheets_and_Info_Booklets/hydros a\%281\%29. pdf (8th Jan 2012)

4. Dawn C.S. Textbook Gynaecology and Contraception 11th Edn. Dawn books Calcutta, 1994 pp:10/216

5. De Cherny et al. Textbook Gynaecology 2nd Edn. New Central Book Agency, Calcutta Increased preg- 
nancy rate with oil soluble Hysterosalpingography dye Fertile/sterile, 1980. 33/407

6. Hareeta samhita, 48/1-8, Hariharaprasad Tripati, Krishnadas Ayurveda Series, Chaukambha Krishnadas Academy, Varanasi, Pp 108.
7. Vriddha Jivaka. Kashyapa Samhita, preached by Maharshi Marica Kasyapa; redacted by Vatsya Commented by Hemraj Sharma, Sutrasthana (27:3), Varanasi, Chaukhambha Samskrita Sansthana, (2012) pg.25.
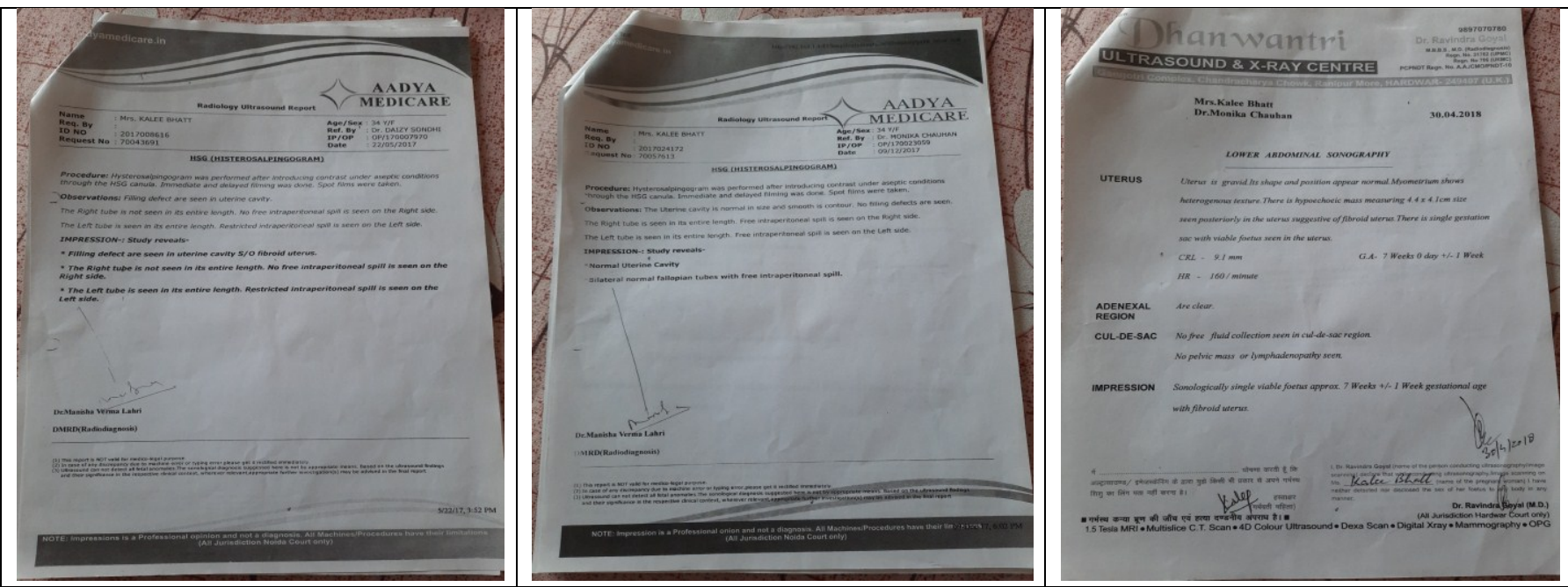

\section{Source of Support: Nil \\ Conflict of Interest: None Declared}

How to cite this URL: Chauhan Monika: Management Of Tubal Blockage By Uttara Basti - A Case Report. International Ayurvedic Medical Journal \{online\} 2021 \{cited March, 2021\} Available from: http://www.iamj.in/posts/images/upload/2868 2871.pdf 